\title{
The Protestant Principle and the Situation of the Precariat : a new Approach to Paul Tillich"
}

\author{
Pablo Fernando Dumer**
}

\begin{abstract}
This paper discusses, after a rereading of the paper "The Protestant Principle and the Proletarian Situation", the role of churches in the face of the precariatization of work. The policy of precariatization of work is not accidental, but a demand of the new world economic order. That policy has consequences which challenge Theology to reflect its role in the world. The role and message of Protestant theology are a protest that precarious life is precious. Initially we will analyze the situation of the contemporary proletariat that is here defined as precariat. After that we will reflect on the Protestant principle according to Paul Tillich and the applications to today's context. Finally we will consider some clues to think about the role of Protestantism in the current context.
\end{abstract}

Keywords: Paul Tillich. Protestantism. Precariatization.

\section{O PRINCÍPIO PROTESTANTE E A SITUAÇÃO DO PRECARIA- DO: UMA NOVA ABORDAGEM DE PAUL TILLICH}

\section{RESUMO}

Este artigo discute, a partir de uma releitura do artigo "O Princípio Protestante e a Situação do Proletariado", o papel das igrejas diante da precarização do trabalho. A política de precarização do trabalho não é algo acidental, mas uma demanda da nova ordem econômica mundial.

* This article is the result of a seminar held in partnership between the Faculdades EST in São Leopoldo, Brazil, and the Norwegian School of Theology, Religion and Society in Oslo, Norway, with the title "Precious and Precarious: Precarious Life, Fragile Democracy and the Role of Religiosity and the Churches" in 2018 under the supervision of Professor Dr. André S. Musskopf and Professor Dr. Sturla Stålsett.

** Pablo Fernando Dumer holds a bachelor's and Master's degree in Theology from Faculdades EST and currently conducts doctoral research with the support of CNPq at Faculdades EST, São Leopoldo, RS. Contact: dumerluterano@gmail.com. Curriculum: http://lattes.cnpq.br/7508204500086120. 
Essa política traz consequências que desafiam a teologia a refletir seu papel no mundo. O papel e mensagem da teologia protestante é protesto que a vida precária é preciosa. Inicialmente, analisaremos a situação do proletariado contemporâneo, aqui definido em termos de precariado. Em seguida, refletiremos sobre o princípio protestante segundo Paul Tillich e as aplicações ao contexto atual. Ao final pensaremos em algumas pistas para pensar o papel do protestantismo no contexto atual.

Palavras-chave: Paul Tillich. Protestantismo. Precarização.

\section{BACKGROUND CONSIDERATIONS}

In 1931, the German-American Lutheran theologian Paul Tillich wrote an article called "The Protestant Principle and the Proletarian Situation", in which he reflects on the challenges that the situation of the proletariat posed to Protestantism. ${ }^{1}$ This article emerged from reflections of Tillich's involvement with religious socialism. Since then, the conditions of the proletariat have been changed, especially after policies of social welfare and full employment in capitalist countries. That model, however, has been dismantled globally by reviving workers' movements in defense of their rights and against policies of austerity and precariatization of work.

Most recently, in Brazil, in the midst of the economic and political crisis that affects the country, a labor reform was approved - law 13,467 of July 13, 2017 (Reformation Jubilee Year) - despite numerous strikes and protests of various entities, including Catholic and Protestant churches (IHU, 2017).

In this paper, we want to reflect on the role of churches, specifically Protestants, in the face of the precariatization of work, on the relation of Protestantism to the proletariat of our time, which is here defined as precariat. Initially we will analyze the situation of the contemporary proletariat. After that we will reflect on the Protestant principle according to Paul Tillich and the applications to our context.

The article was originally published under the title Protestantisches Prinzip und Proletarische Situation. Bonn: Friedrich Cohen, 1931. 
Finally, through a synthesis, we will consider some clues to think about the role of Protestantism in the current context.

\section{THE SITUATION OF THE PRECARIAT}

The policy of precariatization of work is not accidental, but a demand of the new world economic order. Since the fall of the Berlin Wall, neoliberalism has established itself as a unique model through economic interventions, especially in peripheral countries. One of the main measures adopted is called flexibilization of work. Flexibilization of work means "making employees more insecure" (STANDING, 2011 , p. 6). That flexibility means the precariatization of work and the relationships between workers, and hence, precariat arises as term.

The precariat has relations with the proletariat, but it is different. For Guy Standing, British economist, a proletariat suggests

a society consisting mostly of workers in long-term, stable, fixed-hour jobs with established routes of advancement, subject to unionisation and collective agreements, with job titles their fathers and mothers would have understood, facing local employers whose names and features they were familiar with (STANDING, 2011, p. 6).

We could define precariat as a precarious proletariat. Standing also defines it as a class-in-the-making (STANDING, 2011, p. 7). It is not appropriate here to discuss the history of the concept, its definition matters more. For this it is also important to characterize what the precariat is not.

For Standing, precariat is not synonymous with "working poor" or "insecure employment", although it is also. "The precariousness also implies a lack of a secure work-based identity" (STANDING, 2011, p. 9). By author's analysis, "the precariat consists of people who lack the seven forms of labour-related security". They are: labour market security; employment security; job security; work security; skill reproduction security; income security; and representation security (STANDING, 2011, p. 10).

The main characteristic of the precariat, for Standing, is the lack of identity and community. That is, what characterizes the precariat 
"is not the level of money wages or income earned at any particular moment but the lack of community support in times of need, lack of assured enterprise or state benefits, and lack of private benefits to supplement money earnings" (STANDING, 2011, p. 12). It is not just about "labour insecurity and insecure social income", but the lack "a work-based identity" (STANDING, 2011, p. 12). So we could say that the precariat consists of an anthropological condition.

So, a person who is in the precariat is "precariatized". For Standing: "To be precariatised is to be subject to pressures and experiences that lead to a precariat existence, of living in the present, without a secure identity or sense of development achieved through work and lifestyle" (STANDING, 2011, p. 16). That condition of being "precariatized" leads to a state of existence characterized by: anger, anomie, anxiety and alienation. Let us analyze these anthropological characteristics of precariat.

A person in the precariat is angry. Anger is different from hate. Anger is a reactive feeling. "The anger stems from frustration at the seemingly blocked avenues for advancing a meaningful file and from a sense of relative deprivation" (STANDING, 2011, p. 19). It is a reaction to that insecurity, that frustration of its realization as an individual. That frustration comes "not only because a lifetime of flexi-jobs beckons, with all the insecurities that come with them, but also because those jobs involve no construction of trusting relationships built up in meaningful structures or networks" (STANDING, 2011, p. 19-20). That frustration arises from the lack of sense-building in the condition of the precariat.

The second aspect consists of anomie. It

comes from a listlessness associated with sustained defeat, compounded by the condemnation lobbed at many in the precariat by politicians and middle-class commentators castigating them as lazy, directionless, undeserving, socially irresponsible or worse (STANDING, 2011, p. 20).

In Brazil, this phenomenon is moreover fomented by mass media (most of it, conservative) and justifies austerity measures in social programs for precariatized people, such as the constant criticism of the Bolsa Família Programme or even scholarships to the university. 
The third aspect is anxiety, that is,

chronic insecurity associated not only with teetering on the edge, knowing that one mistake or one piece of bad luck could tip the balance between modest dignity and being a bag lady, but also with a fear of losing what they possess even while feeling cheated by not having more (STANDING, 2011, p. 20).

Anxiety is aggravated by insecurity of which forces that the average worker does not even know, such as global financial forces, can take her/him into the streets the next day: forces she/he cannot control.

Finally, people in the precariat "are alienated from their labour and work" (STANDING, 2011, p. 20). For Standing, this last characteristic "arises from knowing that what one is doing is not for one's own purpose or for what one could respect or appreciate; it is simply done for others, at their behest" (STANDING, 2011, p. 20). Alienation, therefore, means living a life without meaning, with tasks that do not build meaning.

In view of those circumstances, Standing concludes that people "in the precariat lack self-esteem and social worth in their work; they must look elsewhere for that esteem, successfully or otherwise" (STANDING, 2011 , p. 21). It may lead to the search for communities that provide identity security strong enough to face that identity insecurity, whether they are extreme right groups, fundamentalist religious groups or the like, which is also a challenge for theology and churches as communities of meaning.

The precariat, in this way, needs to constitute itself as a group, as a class, that is, with common symbols that foster solidarity (STANDING, 2011, p. 3). It should raise its demands for justice and, in this way, build a fair world for all. Is that vocation a theological vocation? Let us first deal with the precariat situation in the middle of which injustices are most strongly manifested: in the Global South.

Despite Standing's effort to analyze precariousness in emerging economies such as China, his analysis is still barely peripheral. The Brazilian sociologist Ruy Braga investigates the precariat situation, and more than that, its rebellion, from three peripheral economies: Portugal, South Africa and Brazil. In his book on labor and neoliberalism, 
Braga states that "the study of the precariat in the global South is able to reveal some central dimensions of the contradictory reproduction of neoliberalism" (BRAGA, 2017, p. 31; own translation). ${ }^{2}$ The concept of Global South here means more than geographic dimension, but serves as a "metaphor of social predation, capable of adding both the processes of national exploration led by the financialization forces and the battles for alternative projects of social and political change" (BRAGA, 2017, p. 30; own translation). ${ }^{3}$ Therefore, it is a space of ambiguity.

For Braga, the constitution of a precariat means the weakening of the union organization. Faced with the crisis that represents trade unionism "other forms of solidarity linked to gender and age range, for example, have emerged in place of those supported predominantly by a masculinized and unionized workforce" (BRAGA, 2017, p. 117; own translation). ${ }^{4}$ It is added to the precariat, therefore, more than just precariatized workers. The precariat gains expressions of gender, generation, race, color, creed, sexual orientation, among others. It is a greater demand than that which trade unionism has become accustomed to dealing with. Precariatization, as a result, involves other aspects of life beyond work: "involves work but overflows to other social domains such as family, community and city" (BRAGA, 2017, p. 139; own translation $) .5$

The Portuguese sociologist Boaventura de Sousa Santos addresses three aspects of exclusion: capitalism, colonialism and patriarchy, which would include class, race and culture, and gender exclusions (SANTOS, 2018, p. 9). The protest of the precarious is now a far more comprehensive protest. It holds the critique of capitalism, but it is also a protest of youths, women, black people and LGBT people, for exam-

2 Original text: "o estudo do precariado no Sul global é capaz de revelar algumas dimensões centrais da reprodução contraditória do neoliberalismo".

3 Original text: "como uma metáfora da espoliação social, capaz de agregar tanto os processos de exploração nacional dirigidos pelas forças de financeirização quanto as batalhas por projetos alternativos de mudança social e política".

4 Original text: "outras formas de solidariedade, ligadas ao gênero e à faixa etária, por exemplo, foram surgindo em substituição àquelas apoiadas predominantemente em uma força de trabalho masculinizada e sindicalizada".

5 Original text: "envolve o trabalho, mas transborda para os outros domínios sociais, como a família, a comunidade e a cidade". 
ple. It includes the ecological agenda, the cultural survival of colonized peoples, land rights, mobility and urban housing. Thus,

in the Global South, it was the task of the precariat, in a difficult alliance with organized labor, to push both the emancipation movement and the social protection movement against the onslaught of the commodification of labor, land, and money, even if the results are very uneven (BRAGA, 2017, p. 251-252; own translation). ${ }^{6}$

Examples of protests from the demands of the precariat, in this regard, occur all over the world: from the Arab Spring to June 2013 in Brazil. The fact that those protests lose their prophetic character over time and are ideologized does not withdraw its transforming force as a rule. This leads directly to the analysis of Tillich's Protestant principle.

\section{A NEW APPROACH TO TILLICH}

Paul Tillich (1886-1965) was a scholar who transcended disciplinary and confessional boundaries of theology. Much of it is due to his involvement with German religious socialism after World War I. From that period, between 1919 and 1933, there are important treatises relating Protestantism and socialism, such as The Socialist Decision and the basic article of this work, The Protestant Principle and the Proletarian Situation.

The question that arises is whether Protestantism has anything to do with the situation of the proletariat. Tillich's answer is: "From many points of view it would seem that Protestantism and the proletarian situation have nothing to do with each other" (TILLICH, 1948, p. 161). In fact, the development of Protestantism occurred allied with feudalism or with the bourgeoisie. Moreover, it was observable in Tillich's time "the political alliance of the proletarian parties with the Catholic party" while the parties close to Protestantism were allied with forces opposed to the working classes (TILLICH, 1948, p. 161). The same phenomenon

\footnotetext{
6 Original text: "no Sul global, coube ao precariado, em uma difícil aliança com o trabalho organizado, a tarefa de impulsionar tanto o movimento de emancipação quanto o movimento pela proteção social contra as investidas da mercantilização do trabalho, da terra e do dinheiro, ainda que os resultados colhidos sejam muito desiguais".
} 
can be observed in present-day Brazil, where "evangelical" parties or politicians are often against the leftist parties, for example.

According to Tillich, it is due to the distrust of Protestantism with socialism (TILLICH, 1948, p. 161-162). Before we enter into this merit it is necessary to observe what Tillich understood by Protestantism and, more specifically, by Protestant principle.

For Tillich: "What makes Protestantism Protestant is the fact that it transcends its own religious and confessional character, that it cannot be identified wholly with any of its particular historical forms" (TILLICH, 1948, p. 162). That is, what causes "Protestantism" to become "Protestant" is the Protestant principle. And what is the Protestant principle? "It is the critical and dynamics source of all Protestant realizations, but is not identical with any of them (...) it is a living, moving, restless power in them" (TILLICH, 1948, p. 163). Protestantism and Protestant principle are not identical, but there would be no Protestantism without the irruption of the Protestant principle in history.

There is no need to rescue the entire history of Protestantism. It is enough to emphasize that the Protestant principle was present in "the protest of the 'protestants' against decisions of the Catholic majority". That protest "contains the divine and human protest against any absolute claim made for a relative reality, even if this claim is made by a Protestant church" (TILLICH, 1948, p. 163). It is also worth noting also the minority character of the protest: it comes from minorities against the majority, against the attempt to absolutize a political, religious, cultural, and economic group and so on. That is why, for Tillich, it "is not strange to the situation of the proletariat in modern society" (TILLICH, 1948, p. 163).

Once one understands what a Protestant principle is for Tillich, one has to ask oneself what is meant by the "proletarian situation". For the theologian:

The proletarian situation is not to be understood as the situation in which all members of the proletariat live. This would be both too narrow and too broad a conception - too narrow, because not only the proletariat, and too broad because not all of the proletariat, are in the proletarian situation (TILLICH, 1948, p. 164). 
And also, for Tillich:

It is taken for granted that the proletarian type is seldom, if ever, wholly realized; that it is, as circumstances chance, subject to modifications which alter the type; and that it is undergoing changes along with capitalism, which is itself in process of development (TILLICH, 1948, p. 164).

Therefore, it is not a static situation but in constant transformation, conditioned to the transformation of capitalism. Tillich does not restrict the concept while making clear that the proletarian situation is a situation at the mercy of capitalism.

In terms of class:

The proletarian situation is thus to be understood as the situation of that class within the capitalist system whose members are dependent exclusively upon the "free" sale of their physical ability to work and whose social destiny is wholly dependent upon the turn of the market (TILLICH, 1948, p. 164).

The proletarian situation transcends a socio-economic condition, it is an anthropological condition, and at this point the Protestant principle begins to participate. The Protestant principle states that the human situation "is basically distorted" (TILLICH, 1948, p. 165). It affirms that about all mankind. But: "In the proletarian situation the perversion of man's nature shows its reality in the social realm" (TILLICH, 1948, p. 166). The situation of the proletariat enables theology to extend the understanding of the sin from the individual sphere to the collective, social and structural one. That perception was fundamental to later Latin American theology.

As for Latin American theology, the perception of sin in its social dimension stems not from restricted theology, but from its relation to the proletarian situation, or from the poor in the Latin American case. For Tillich, "the proletarian consciousness has been aware of the perversion and inner contradiction of a society that permits such a thing to exist as a proletarian situation and the breaking-up of society into classes" (TILLICH, 1948, p. 166). The Protestant principle does not relate its judgment to the human situation only to the soul, but "considers the 
whole man, man as a unity of body and soul, in his relationship with the transcendent" (TILLICH, 1948, p. 167).

For Tillich:

The distorted character of the vital existence of millions and millions of proletarians in city and country is too obvious to need much description. It is worse in some nations than in others and in some sections of a country than in others. It is worst in periods of unemployment, and it is intolerable - leading to mass explosions - in times of protracted mass unemployment. In view of these facts, it is dishonest to use the instinctively materialistic reaction of the proletariat to its fate as an excuse for discrediting the proletarian struggle (TILLICH, 1948, p. 167).

It seems that Tillich described today's post-crisis times of 2008 . In fact, he did not enter into a detailed description of the proletarian situation of his time, also post-crisis, but accentuated the precarious existence of the proletariat, though not in these terms. The proletarian situation is one of insecurity: economic, social and even political. The situation contrasted is the security of the ruling classes and the opposition of proletarian materialism is bourgeois idealism. For Tillich, Protestantism is, in principle, close to this materialism and not to bourgeois idealism (TILLICH, 1948, p. 167-168).

In its genesis, Protestantism was born out of the denunciation of the structures of domination and oppression of the sixteenth century. According to Tillich, it was born fighting ideologies, but it itself "has not escaped the ideologizing of its own principle" (TILLICH, 1948, p. 169). Tillich did not dedicate himself to explaining what ideology is, he just says "false consciousness" in a reference to Marx, thus presupposing his understanding. Nor is it appropriate here to explain the concept, suffice it to say that ideology is opposed to reality, and this materialist.

The Protestant principle, for Tillich, addresses its protest against ideology. The "Protestantism must fight not only against other ideologies but also against its own" (TILLICH, 1948, p. 169). This is because Protestantism always runs the risk of abandoning the Protestant principle and becoming an ideology. It is the proletarian situation that "in forcing Protestantism to bring to the fore the critical element of its own principle, creates the constant suspicion that Protestantism has 
itself become an ideology" (TILLICH, 1948, p. 170). We can say that the relation of Protestantism to the proletarian situation is necessary so that it can remain faithful to its principle.

In the role of revelator of ideologies, Protestantism, for Tillich, approaches the prophetic tradition of the Old Testament (TILLICH, 1948, p. 169-170). The same proximity is claimed by the Liberation Theology in Latin America in its prophetic role of denouncing the structures of oppression and slavery of the peoples of the continent.

In the prophetic tradition: "The Protestant principle overcomes the gap between the sacred and the secular spheres, between priesthood and laity. Protestantism demands a radical laicism. There are in Protestantism only laymen" (TILLICH, 1948, p. 174). The proletarian situation is also secular in character, even in its most radical manifestations, "it has also separated itself from every connection with the church. For this reason, the representatives of most of the Christian churches have challenged socialism, as anti-Christian, anti-religious, and atheistic" (TILLICH, 1948, p. 175). However, the breaking of Protestantism with the proletarian movements would also lead to the breaking with the prophetic content of those movements (TILLICH, 1948, p. 176).

But why did Protestantism deviate from the Protestant principle? Several reasons. First, by the process of "hardening into dogma" of the period immediately after the Reformation (TILLICH, 1948, p. 176). Another reason was the progressive dependence of Protestantism on the hierarchy of nation states. "Luther's decision in connection with the Peasant's Revolt made it a permanent necessity for Lutheranism to depend upon absolutism and to repudiate democratic revolutionary tendencies" (TILLICH, 1948, p. 179).

Protestantism, particularly Lutheranism, developed against the situation of the proletariat, leaving its Protestant principle aside. Tillich does not carry out a triumphalist revision of Protestantism in advocating a Protestant principle that would not be foreign to the situation of the proletariat. On the contrary, it is a challenge. "The religious socialists have set for themselves the goal of freeing Protestantism from the sociological attachments resulting from its antiproletarian past" (TILLICH, 1948, p. 180). 
The greatest challenge of Protestantism in the face of the proletariat is to "decide for the Protestant principle as against historical Protestantism" (TILLICH, 1948, p. 181). It is a radical decision. Perhaps, the necessary decision after 500 years of the Reformation.

\section{OUTROS 500?}

There is an expression of medieval Portuguese origin to designate something of real value. It says "another five hundred." The expression comes from the legal framework. In case of any injury, the aggressor would receive a penalty of 500 soldos (currency at that time), if the victim were a noble, and 300 soldos, if she/he were a plebeian - if justice were done. A poor man would possibly never receive anything, but if he were a nobleman, he certainly would. And if the injury were committed again, another 500 (RODRIGUES, 2014). The expression became commonplace in Brazilian daily life and curiously became a motto for the Jubilee of the Reformation in Brazil in 2017: now there'll be another 500 .

Although it may have been unintentional, the use of such expression denotes the distance from Protestantism to the situation of the proletariat (or to the precariat). In the aftermath of Protestant values for the future of Protestantism, the proletariat and/or the precariat will probably never receive anything, while to the rich ones, another 500 .

Asking himself for the future of Protestantism in Latin America, the Brazilian Protestant theologian Rubem Alves in 1970 said:

Indeed, the present crises that the historic Protestant churches are fracturing on our continent lead us to seriously doubt that Protestantism is on the way to some future that can be described as having some positive significance (ALVES, 1982, p. 130; own translation). ${ }^{7}$

Although he carried on a dialogue with Tillich in his article, Alves knew that Tillich had written for European reality and that content could not merely be transferred to Latin America. One of the reasons

7 Original text: "Realmente, as crises que no presente estão fraturando as igrejas protestantes históricas em nosso continente nos levam a duvidar, seriamente, que o Protestantismo esteja a caminho de algum futuro que possa ser descrito como de alguma significação positiva". 
is that, for Alves, we cannot speak about an "end of the Protestant Era" in Latin America, because we never had it. "Protestant Era," for the Brazilian theologian, "is an expression that denotes the creative power of Protestantism to vitalize a civilization" (ALVES, 1982, p. 130-131; own translation). ${ }^{8}$ In relation to Latin American, according to Alves's analysis, "Protestantism lost its vigor before fertilizing it with what it had of most creative" (ALVES, 1982, p. 131; own translation). ${ }^{9}$ The mark of the deterioration of Protestantism in Latin America is its "obsession with the past and its preservation" (ALVES, 1982, p. 131; own translation). ${ }^{10}$

Rubem Alves designed this deterioration through the opposition between structure and community. Regarding the "structure", Alves argued that

the dead world lingers among living people through the structures it has created: structures of thought, language, community, power. Structures that once were the authentic expression of a community that created them in order to express themselves in their world. But when the community that created those structures and the world for which they were created passed away, they continued. And through their presence men are still chained to a world that has already died (ALVES, 1982, p. 131; own translation). ${ }^{11}$

For Alves, the Protestant principle of Protestantism is "the community (koinonia)"; "Protestantism was born as a rediscovery of the community" (ALVES, 1982, p. 133; own translation). ${ }^{12}$ This principle, as Alves understood, would be basically the contracting between human reality, life, and dogmatic and/or ideological structures. Rubem Alves wrote about the Protestantism of which he had been part: Presbyterian

8 Original text: "é uma expressão que denota o poder criador do Protestantismo para vitalizar uma civilização".

9 Original text: "o Protestantismo envelheceu muito antes de fecunda-lo com aquilo que de mais criador ele possuía".

10 Original text: "obsessão pelo passado e a sua preservação".

11 Original text: "o mundo morto se prolonga entre os vivos através das estruturas que ele criou: estruturas de pensamento, de linguagem, de comunidade, de poder. Estruturas que um dia foram a expressão autêntica de uma comunidade que as criou a fim de expressar-se no seu mundo. Mas quando a comunidade que as criou e o mundo para que foram criadas passaram e morreram, elas continuaram. E através da sua presença os homens continuam acorrentados a um mundo que já morreu".

12 Original text: "o Protestantismo nasceu como uma redescoberta da comunidade". 
and Evangelical, which very early in Brazil hardened itself as dogmatic and aligned with the political and economic status quo of the country, that is, simultaneously conservative and neoliberal with no room for dialogue with the proletarian situation. Added to that, there were the repressive alignment of churches and the military dictatorship in Brazil, of which Rubem Alves himself was a victim.

Through his own biography, Alves concludes that the Protestant principle and dogmatic and repressive hardening are irreconcilable. He writes: "Not a few Protestants have concluded that to find the community it is necessary to leave the traditional ecclesiastical structures" (ALVES, 1982, p. 147; own translation). ${ }^{13}$ His conclusion, therefore, is very similar to that of Tillich. It is necessary to opt for the Protestant principle against the historical Protestantism. Alves returns to his initial question: "Is there any future for Protestantism? Only if we understand that the structures that call themselves Protestants, to a large extent, are responsible for the eclipse of Protestant communities" (ALVES, 1982, p. 147; own translation). ${ }^{14}$

Today the situation in Brazil is not very different. The churches of greater expression have long abandoned the Protestant principle in the name of their alignment with the status quo. Their only protest is protesting against the protests that come from the precariat: from precariatized workers, women, youth, black people and LGBT people.

The Protestant principle, within Protestantism today, survives in small groups, organizations in solidarity with the precarious. We could say that the Protestant principle survives just as in the Reformation: as a minority protest. Protestantism capable of allying itself with the precariat is a minority and, thus, itself belonging to the precariat.

\section{FINAL CONSIDERATIONS}

This article proposes to reflect on the role of the Protestant principle in face of the situation of the precariat. It is difficult to describe the class of the precariat. It is a plural group. It would not be correct

13 Original text: "Não são poucos os protestantes que concluíram que para achar a comunidade é necessário sair das estruturas eclesiásticas tradicionais".

14 Original text: “"'Haverá algum futuro para o Protestantismo? Somente se compreendermos que as estruturas que se chamam protestantes são, em grande medida, as responsáveis pelo eclipse das comunidades protestantes". 
to identify it only as of poor workers because there are more groups that fit into the precariat condition: women, black people, youth, LGBT people and others groups. In the same way it is essential to maintain the character of class and criticism of capitalism. More than working conditions, relationships are also precarious. Therefore, for Standing, the main characteristic of the precariat is the lack of identity and community, that is, its precariatization encompasses the individual and collective levels.

The anthropological condition of the precariat defined in terms of anger, anomie, anxiety, and alienation is close to other analyzes of Tillich that were not possible in this article: anxiety and alienation are densely analyzed, at individual and collective levels in "The courage to be" of Tillich. The conclusion is that the precarious suffers from the lack of construction of meaning. For that, symbols are important. Standing understands the need for symbols but he proposes none. For Tillich, those symbols are theological. Rubem Alves rightly interprets the Protestant principle as a community.

As a community, Protestantism retains its minority character and in immediate solidarity with minorities. That solidarity will often cause Protestantism to decide against its structures. Every Protestant decision is against structures that are not vivifying. The condition of being of Protestantism is protest. And the condition of being of the precariat is also that of protest. Then the two groups meet. In Latin American context, Protestantism must have the humility to recognize itself as a precarious existence, therefore, belonging to the precariat.

However, it is not to be expected that there will be great transformations resulting from Protestant and precariat protest. A characteristic of the precariat is having to deal with frustration. Its protest is precarious and causes very precarious changes. Its protest is from the minority and produces very small changes. But protest transforms; transforms the Protestant person, who has opted against structures: she/ he begins to construct meaning and acquire meaning - her/his precarious life is precious, and it is certainty what empowers her/him to protest against the precariatization of life. 


\section{BIBLIOGRAPHIC REFERENCE}

ALVES, Rubem. Dogmatismo e tolerância. São Paulo: Paulinas, 1982.

BRAGA, Ruy. A rebeldia do precariado: trabalho e neoliberalismo no Sul global. São Paulo: Boitempo, 2017.

SANTOS, Boaventura de Sousa. Esquerdas do mundo, uni-vos! São Paulo: Boitempo, 2018.

STANDING, Guy. The Precariat. The New Dangerous Class. London: Bloomsbury Academic, 2011.

TILLICH, Paul. The Protestant Era. Chicago: University of Chicago Press, 1948.

\section{ELECTRONIC MEDIA}

IHU. Igrejas Evangélicas Históricas e Aliança Evangélica assinam manifesto contra a Reforma da Previdência. April, 2017. Accessed on: <http://www.ihu. unisinos.br/78-noticias/566941-igrejas-evangelicas-historicas-e-alianca-evangelica-assinam-manifesto-contra-a-reforma-da-previdencia> Viewed: May 27, 2019.

RODRIGUES, Sérgio. De onde veio a expressão 'outros quinhentos'? January, 2014. Accessed on: <https://veja.abril.com.br/blog/sobre-palavras/de-onde-veioa-expressao-outros-quinhentos/> Viewed: July 18, 2018. 